Original Research Article

\title{
Comparative study of impact of marketing strategies of pharmaceutical houses on prescription practices of doctors rural vs urban
}

\author{
Shallini Gupta $^{1 *}$, Kanika Khajuria ${ }^{1}$, Vijay Khajuria ${ }^{1}$, Niraj Kumar ${ }^{2}$
}

\begin{abstract}
${ }^{1}$ Department of Pharmacology, Government Medical College, Jammu, J\&K, India ${ }^{2}$ Department of Pediatrics, Sub district Hospital, Akhnoor, Jammu. J\&K, India
\end{abstract}

Received: 12 March 2018

Revised: 04 April 2018

Accepted: 07 April 2018

*Correspondence to: Dr. Shallini Gupta, Email: shallinirajkdr@ gmail.com

Copyright: (C) the author(s), publisher and licensee Medip Academy. This is an openaccess article distributed under the terms of the Creative Commons Attribution NonCommercial License, which permits unrestricted noncommercial use, distribution, and reproduction in any medium, provided the original work is properly cited.

\begin{abstract}
Background: Indian pharmaceutical market is fast going and there is a stiff competition amongst them as single product is marketed by different brand names. The pharmaceutical houses adopt different strategies to influence the physician to promote their products. These strategies are known to influence the prescription behaviour of physician, which may have variable impact among rural and urban doctors. Aim of the study was to compare the impact of marketing strategies of pharmaceutical houses on prescription practices of rural and urban doctors.

Methods: The current crossover study was conducted among urban and rural doctors. A questionnaire consisting of 17 questions was presented to the doctors and their responses regarding different aspects of marketing strategies was recorded. Comparison between two groups was done using unpaired t-test.

Results: Different strategies had impact on prescription pattern of doctors working in rural and urban institutions. All 17 parameters were affected similarly except e-mailing where urban doctors were more influenced $(\mathrm{p}=0.005)$.

Conclusions: Present study indicates marketing strategies by different pharmaceutical houses do influence prescription pattern of physicians. Both urban and rural doctors were similarly affected except e- mailing which had more impact on urban doctors.
\end{abstract}

Keywords: Marketing strategies, Pharmaceutical houses, Prescription pattern, Rural doctors, Urban doctors

\section{INTRODUCTION}

One of the world's largest industry is Pharmaceutical industry with revenues turnover of US $\$ 2.8$ trillion. ${ }^{1}$ The population growth coupled with economic development in India has lead to increased demand to the health care services and need for availability of pharmaceutical products. Indian pharmaceutical market is the fastest growing and reached turnover of US\$ 20 billion in 2015 and is expected to reach US\$ 55 billion by $2020 .^{2}$ There are number of local and global players in Indian pharmaceutical industry and provide stiff competition to each other as a single pharmaceutical product is marketed by different brand names by different companies.

Though the patient is the end user of pharmaceutical products but the physician remains the crucial link between pharmaceutical house and the patient. This is in contradiction to the usual marketing practices as mostly the consumer is the primary target. This unique situation results in targeting physician rather than consumer by the pharmaceutical houses. Therefore, the thrust of the pharmaceutical houses is always to influence the physician by adopting different marketing strategies and relationship between physician and industry is common and vary 
according to specialty, practice type and professional activities. $^{3}$

These strategies are known to influence physicians as number of studies have shown the impact of them on prescribing behaviour. ${ }^{4,5}$ However, most of these studies are urban based. On review of literature we failed to come across any study originating from rural based institutions and comparing the impact of these marketing strategies with doctors from urban based hospitals. It is a well known that the reach of pharmaceutical houses to the rural area may not be same as in urban areas. Therefore, the present study was conceived to evaluate and compare the impact of different marketing strategies adopted by pharmaceutical industry to influence physicians prescribing behaviour in urban and rural areas.

\section{METHODS}

The current observational, cross-sectional one point study was undertaken in Sub district hospital Akhnoor from rural and doctors in Jammu city from urban area. The institutional ethics committee approval was obtained prior to the start of study. A detailed questionnaire was prepared and presented to physicians and their responses were recorded. Questionnaire, consisted set of 17 questions designed according to objective, was used as research instrument. Data was collected through a self-administered questionnaire which covered the different aspects of marketing strategies. The effectiveness of the promotional strategies on prescription behaviour was marked in a five point Likert scale (7) ranging from "Not At All Important effective" ( score $=1$ ) to "Very Important" (score=5).
Important factors applicable were selected after discussions with the physicians. Some of the factors selected were Print and Broadcast advertisements, Packaging inserts Audio-visual material, Exhibits in conferences, Product Launch parties and Peer group/senior doctor reference. In total 17 factors were chosen, which were relevant and included the major marketing communication elements.

\section{Statistical analysis}

Intergroup comparison between urban and rural doctors was carried out by using unpaired t- test. $P$ value $\leq 0.05$ was considered significant.

\section{RESULTS}

There were 62 physicians in total responded to the questionnaire. 32 in rural and 30 in urban group, respectively. Their responses were recorded using five point Likert scale ranging from "Not At All Important effective" (score =1) -to "Very Important" ( score =5), final mean score was calculated using excel.

Analysis of the responses of doctors based in both urban as well as rural area revealed that Cost of product, Seminars conducted by company, Publications, Reputation of company, Brochures and Booklets, packaging inserts, exhibits and conferences, catalogs were the most common factors considered by the physicians while prescribing drugs.

Table 1: Comparison of impact of different marketing communication strategies on doctors-rural vs urban.

\begin{tabular}{|c|c|c|c|}
\hline \multirow[b]{2}{*}{ Marketing communication strategies } & \multicolumn{2}{|l|}{ Scores } & \multirow[b]{2}{*}{$\begin{array}{l}\text { Statistical interpretation } \\
\text { (Unpaired 't' test) }\end{array}$} \\
\hline & $\begin{array}{l}\text { Rural }(n=32) \\
(\text { Mean } \pm \text { SD })\end{array}$ & $\begin{array}{l}\text { Urban }(n=30) \\
(\text { Mean } \pm \text { SD })\end{array}$ & \\
\hline Cost of product & $3.37 \pm 1.28$ & $3.23 \pm 1.04$ & $\mathrm{t}=0.4 ; \mathrm{p}=0.63 ; \mathrm{NS}$ \\
\hline Seminars & $2.62 \pm 1.03$ & $3 \pm 0.98$ & $\mathrm{t}=1.48 ; \mathrm{p}=0.14 ; \mathrm{NS}$ \\
\hline Publications & $2.75 \pm 0.95$ & $2.86 \pm 1.19$ & $\mathrm{t}=0.40 ; \mathrm{p}=0.68 ; \mathrm{NS}$ \\
\hline Reputation of company & $2.96 \pm 1.20$ & $2.96 \pm 1.06$ & $\mathrm{t}=0.00 ; \mathrm{p}=1.00 ; \mathrm{NS}$ \\
\hline Brochures and booklets & $2.59 \pm 1.13$ & $2.06 \pm 1.28$ & $\mathrm{t}=1.73 ; \mathrm{p}=0.08 ; \mathrm{NS}$ \\
\hline Packaging inserts & $2.59 \pm 1.07$ & $2.03 \pm 1.15$ & $\mathrm{t}=1.98 ; \mathrm{p}=0.05 ; \mathrm{NS}$ \\
\hline Senior doctor reference & $2.56 \pm 1.29$ & $2.46 \pm 1.50$ & $\mathrm{t}=0.28 ; \mathrm{p}=0.77 ; \mathrm{NS}$ \\
\hline Exhibits in conferences & $2.34 \pm 1.45$ & $2 \pm 1.17$ & $\mathrm{t}=1.01 ; \mathrm{p}=0.31 ; \mathrm{NS}$ \\
\hline Catalogs & $2.28 \pm 0.92$ & $1.8 \pm 1.09$ & $\mathrm{t}=1.87 ; \mathrm{p}=0.06 ; \mathrm{NS}$ \\
\hline Audio visual material & $2.25 \pm 0.87$ & $2.36 \pm 1.15$ & $\mathrm{t}=0.42 ; \mathrm{p}=0.67 ; \mathrm{NS}$ \\
\hline Launch parties & $2.21 \pm 1.31$ & $2.3 \pm 1.31$ & $\mathrm{t}=0.27 ; \mathrm{p}=0.78 ; \mathrm{NS}$ \\
\hline Sponsoring medical fraternity & $1.81 \pm 1.17$ & $2.4 \pm 1.30$ & $\mathrm{t}=1.80 ; \mathrm{p}=0.06 ; \mathrm{NS}$ \\
\hline Samples & $1.96 \pm 1.28$ & $2.1 \pm 1.55$ & $\mathrm{t}=0.45 ; \mathrm{p}=0.65 ; \mathrm{NS}$ \\
\hline Gifts & $1.53 \pm 0.91$ & $1.6 \pm 1.06$ & $\mathrm{t}=0.27 ; \mathrm{p}=0.78 ; \mathrm{NS}$ \\
\hline Print and broadcast ads & $1.93 \pm 1.31$ & $2.03 \pm 1.15$ & $\mathrm{t}=0.31 ; \mathrm{p}=0.75 ; \mathrm{NS}$ \\
\hline Directories & $2.25 \pm 0.87$ & $2.46 \pm 1.50$ & $\mathrm{t}=0.67 ; \mathrm{p}=0.49 ; \mathrm{NS}$ \\
\hline Mailing & $1.53 \pm 0.91$ & $2.33 \pm 1.24$ & $\mathrm{t}=2.90 ; \mathrm{p}=0.005 ; \mathrm{HS}$ \\
\hline
\end{tabular}

NS - Not significant; HS - Highly significant 
Mailing information about products, Gifts and Print and Broadcast advertisements were least considered while prescribing. While comparing responses based on marketing communication strategies for promoting pharmaceutical products of both urban and rural doctors, statistically it was found that there were no differences on most of the factors except e-mail which was found to be significantly more preferred strategy for marketing communication by urban doctors as compared to rural $\operatorname{doctors}(\mathrm{p}=0.005)$ (Table 1$)$.

\section{DISCUSSION}

Promotional practices by pharmaceutical houses is a well known commercial activity to influence the prescribing behaviour of doctors since they and not the final consumer i.e. patient decides the consumption of product. Most of the companies have identical products with different brand names so it is always their endeavour to influence the physicians to boost the sale of their products.

Pharmaceutical companies spent a lot of money by adopting multiple approaches for drug promotion. Drug promotion has an important impact on rational use of drugs and price. WHO defines endeavour to influence prescription pattern of doctors in pharmaceutical promotion as all information and favour of their brands by offering various kinds of persuasive activities by manufacturers and distributors, the promotional inputs such as samples, gifts and sponsoring effect of which is to induce the prescription, supply or use. ${ }^{6}$

Promotional strategies adopted by pharmaceutical houses are advertisements, sale promotions, public relations, personal selling and direct marketing. ${ }^{7}$ Advertisement usually refer to non personal promotion of drug through magazines and banners in conferences, sales promotion refer to short term incentives including brand reminders like letter pads, pens, paper weights and costly gifts.

Public relations involve launch parties and lectures by senior doctors. Personal selling is detailing of the product by representative of company and comprise of drug sampling while direct marketing refers to sending of product information or advertisement through e mail, post, telephone.

Since the availability of these strategies may be different in rural compared urban areas therefore the impact of these strategies is likely to be different. The present study was undertaken to examine the extent of influence of these promotional strategies on prescribing pattern of rural as well as urban physicians and compare them.

Outcome of the study shows that the cost of the product was the most important deciding factor while prescribing drug. Seminars, publications, brochures and booklets, reputation of company, packaging inserts, senior doctor reference and directories like MIMS, SIMS and launch parties were other factors that influenced the prescription.
Samples, sponsoring medical fraternity, print and broadcast ads, gifts and mailing were the least influencing factors.

Gift that come under sale promotion are usually thought to be the most influencing factor while prescribing however in the current study it comes to be least influencing factor amongst all the marketing communicating strategies. This may not be actual situation since physician may not have revealed as MCI has banned doctors from accepting gifts or any monetarily benefits from pharmaceutical or health care industry. ${ }^{8}$ However research work earlier do suggest that gifts influence the behaviour of the recipient. ${ }^{9}$

Similar results are also revealed by Narendra R et al. ${ }^{10}$ Who also showed that sampling was not a major influencing factor as per the outcome of the study though this is usually adopted by the sales representative. This contradicts the usual prevalent belief that sampling is a major factor that influence the prescription.

Comparison of the responses of doctors posted in rural and urban areas showed that they were identically influenced by these strategies. Only mailing was more significant in urban than rural doctors. This could be due to easy availability of internet in urban than in rural areas.

\section{CONCLUSION}

Current study reveals that different marketing communication strategies of pharmaceutical houses have similar impact on prescribing behaviour of doctors working in both rural as well as urban. However, Emailing had more impact in urban doctors.

\section{ACKNOWLEDGEMENTS}

Authors would like to thank Dr. Naveen, for his support during study.

Funding: No funding sources

Conflict of interest: None declared

Ethical approval: The study was approved by the Institutional Ethics Committee

\section{REFERENCES}

1. Bhoot AJ. A review of marketing strategies and TQM of pharmaceutical companies in India, Paripex Indian J Res (PIJR). 2012;1(9):1-2.

2. Pharma industry in India. Pharma sector. Overview, market size, analysis. Sectoral report; Jan 2018. Available at: https:// www.ibef.org/industry> pharma.

3. Campbell EG, Gruen RL, Mountford J, Miller LG, Cleary PD, Blumenthal D. $\mathrm{N}$ Engl J Med. 2007;356:1742-50.

4. Kasliwal N, Bansal I. Influence of Pharmaceutical Promotional tools on doctors prescribing behavior: An exploratory study. Indian journal of Marketing. 2013;43(8):36319. 
5. Khajuria A, Khajuria V. Impact of Pharmaceutical marketing communication strategies on prescription practices of physicians. Research Journal of Pharmaceutical, Biological and Chemical Sciences. 2013;4(3):882.

6. Arora U, Taneja G. An analytical study of physicians behaviour towards pharmaceutical products. Indian journal of Marketing. 2006;36(11).

7. Kotler P. Marketing management. New Delhi: Prentice Hall of India; 1999.

8. Medical Council of India, Amendment Notification, New Delhi, The 10th December 2009. No Mci211(1)/2009(Ethics)/55667(http://www.mciindia. org/RulesandRegulations/Codeof MedicalEthicsRegulations2002.aspx).
9. Wazana A. physicians and the pharmaceutical industry, is a gift ever just a gift? JAMA. 2000;283:373-80.

10. Narendran R, Narendranathan $M$. influence of pharmaceutical marketing on prescription pattern of physicians. Journal of Indian Medical association. 2013;111(1):47-50.

Cite this article as: Gupta S, Khajuria K, Khajuria V, Kumar N. Comparative study of impact of marketing strategies of pharmaceutical houses on prescription practices of doctors rural vs urban. Int $\mathrm{J}$ Basic Clin Pharmacol 2018;7:1016-9. 